\title{
ENGLISH WRITING SKILLS THROUGH PERCEPTION OF SIRI'CULTURAL VALUES: OPTIMISM, SOCIAL SUPPORT, AND ACADEMIC SELF-EFFICACY
}

\author{
Subhan Ajrin Sudirman*, Achmad Nurmandi, Khoiruddin Bashori \\ Universitas Muhammadiyah Yogyakarta, Indonesia \\ *e-mail: subhansudirman@uinib.ac.id
}

\begin{abstract}
The mastery of foreign languages, specifically English which is applied predominantly in the international scope, is one form of improving the quality of an indvidual. This research aims to find empirical supports for the relationships between optimism, social support, academic self-efficacy and mastery of academic English paragraph writing skills mediated by perceptions of Siri' cultural values. Siri' cultural values are living laws which become the guidance to think, act, and build interpersonal relationship with other individuals. The data in this study were collected through writing tasks and scales of optimism, social support, academic self-efficacy, and perceptions of Siri' cultural values. The data were subsequently analyzed using structural equation modeling. The results show that the relationships between optimism, social support, and academic self-efficacy and mastery of academic English paragraph writing skills will be stronger when students are able to perceive cultural values of Siri' well. It is worthy of attention for educators and education observers that when students are required to be able to master a learning material, teachers need to see it not only from the cognitive side concerned, but also from the psychological side of the students.
\end{abstract}

Keywords: optimism, social support, academic self-efficacy, siri'cultural values, English writing skills

\section{KETERAMPILAN MENULIS BAHASA INGGRIS MELALUI PERSEPSI NILAI BUDAYA PERSEPSI: OPTIMISME, DUKUNGAN SOSIAL, EFIKASI DIRI AKADEMIK}

\begin{abstract}
Abstrak: Penguasaan bahasa asing, terutama bahasa Inggris yang digunakan terutama dalam kancah internasional adalah salah satu bentuk peningkatan kualitas individu. Penelitian ini bertujuan untuk menemukan dukungan empiris hubungan antara optimisme, dukungan sosial, efikasi diri akademik dengan penguasaan keterampilan menulis paragraf bahasa Inggris yang dimediasi oleh persepsi nilai-nilai budaya Siri'. Nilai budaya siri merupakan hukum adat yang jadi pedoman dalam berpikir, bertindak, serta dalam membangun hubungan interpersonal dengan individu lain. Instrumen penelitian ini menggunakan writing task, skala optimisme, skala dukungan sosial, skala efikasi diri akademik, dan skala persepsi nilai budaya Siri'. Data dianalisis menggunakan pemodelan persamaan struktural. Hasil penelitian menunjukkan bahwa hubungan antara optimisme, dukungan sosial, efikasi diri akademik, dan penguasaan keterampilan menulis paragraf bahasa Inggris akademik akan lebih kuat jika siswa mampu memahami nilai-nilai budaya Siri' dengan baik. Hal ini layak menjadi perhatian bagi pendidik dan pemerhati pendidikan bahwa ketika siswa dituntut untuk dapat menguasai sebuah materi belajar tidak hanya dari sisi kognitifnya saja yang diperhatikan, akan tetapi juga sisi psikologis dari peserta didik.
\end{abstract}

Kata Kunci: optimisme, dukungan sosial, efikasi diri akademik, persepsi nilai budaya siri', keterampilan menulis bahasa Inggris

\section{INTRODUCTION}

Mastering English language skills are important for Indonesian students. One of the components in mastering English language skills is writing skill, of which is an activity associated with cognitive processes and expressions including the other three language skills namely listening, speaking, and reading. Niño \& Páez
(2018) mention that there are many factors that affect the process toward learning outcomes. Broadly speaking, first, there are internal factors involving the student's physiological and psychological state. Physiological state includes health, sensory, and other physical conditions, while psychological state includes interest, self-concept, self-efficacy, intelligence, 
and talent. Second, there external factors such as the student's social environment, school environment, teachers, and social non-social factors such as the physical environment, learning, and teaching materials studied.

Indonesia is a country which has wide diversity of cultures, some of them existed in South Sulawesi province where Makassar is the capital city. This province is inhabited by four major ethnicities, namely Makassar, Bugis, Mandar, and Toraja. One of the norms representing identity and character of BugisMakassar in South Sulawesi is Siri' culture. This culture has four elements within, they are self-actualization, modesty, loyalty, and honesty. Siri' cultural value is a living law which becomes a guidance to think, act, and build interpersonal relationship with other individuals. Siri' cultural value is gained from socialization and manifested in every aspect of life, including in defining mindset and behavior of students.

Rahman (2007) states that teaching writing skills is complex and difficult since writing requires mastery of grammatical, rhetorical, and conceptual elements and other considerations. Therefore, the teaching of writing must apply an acceptable strategy. Nevertheless, the reality of field shows that the teaching of writing remains unsatisfactory.

Indeed, from an educational perspective, there are many factors that influence the educational process. Cultural values influence students' writing skills, hence Siri' cultural values are assumed to strengthen or perhaps weaken the influence of optimism, social support, and academic self-efficacy on students' mastery of English paragraph writing skills.

English is the first foreign language that is considered important as a means for the absorption and development of science, technology, arts and culture, and fostering relationships with other nations (Alqahtani, 2015). English is also one of the main school subjects tested in national exams (UN), moreover this means the challenge for education is to play a role in the millennial era. If good mastery of English is important for students in Indonesia, it automatically means mastery of language learning materials, one of which is paragraph writing skills also important for students in Indonesia, since mastering English paragraph writing skills is one reflection of learning outcomes that must be achieved by students in their efforts to excel. One component in mastering English is the writing skills component. Writing is an activity related to cognitive processes and as a form of expression associated with the three other components of language acquisition, such as listening, speaking, and reading. The four language skills are complementary.

According to Vygotsky, writing can improve cognitive functions, including critical thinking, and problem solving (Schultz, 2009). In line with Vygotsky's opinion, Schultz (2009) states that having skills in writing especially in English will make students use a meta-cognitive framework that is more effective than just thinking aloud when they write.

Many factors affect the mastery of learning material. Broadly speaking, it can be divided into two, namely internal and external factors. Internal factors are psychological factors of the students themselves. Research from Morton, Mergler, \& Boman (2014) states that optimism and self-efficacy have a significant correlation to the mastery of learning material. While self-efficacy is also a predictor for measuring the ability of individuals in writing (Bruning, Dempsey, Kauffman, McKim, \& Zumbrunn, 2013; Tsang, Hui, \& Law, 2011; Jalaluddin, Paramasivam, Husain, \& Bakar, 2015). While external factors that influence mastery of learning material include social support, the attention and appreciation of students also influence the level of student learning achievement (Song, Bong, Lee, \& Kim, 2015; Mackinnon, 2012; Sivandani, Koohbanani, \& Vahidi, 2013).

The perception of siri cultural values referred to scholarship, honesty, courage, assertiveness, courage to compete, hard work, and perseverance. Integration of siri values in the context of education will be able to direct the orientation of education as forming personality. The philosophy of Siri' value itself is expected to be able to be internalized into the joints of education which starts from the planning, implementation, and evaluation at the same time. Students are expected to have a clear understanding of the cultural values of Siri' which can positively influence the internal conditions of students in order to improve their learning achievement, especially in English subjects (Warikoo \& Carter, 2009; Jaeger, 2011). In this research, specifically, the researcher 
has highlighted internal factors, in this case, optimism, social support, students' academic self-efficacy. Besides optimism, social support, and academic self-efficacy, the perceptions of the value of Siri' culture is also considered in affecting mastery of writing skills for students to excel in the subjects of English. Siri' cultural values are assumed to strengthen or weaken the influence of optimism, social support, and academic self-efficacy on students' mastery of paragraph writing skills in English.

Some researches indicate that supporting those closest to the child, i.e., praise by one of the parents, appreciation of the child's desires, and support from teachers have the ability to create conditions that are effective in the classroom for enhancing students' skills in mastering classroom subjects, including writing skills in English (Wibrowski, Matthews, \& Kitsantas, 2017). Furthermore, parents' support to their children can be shown by monitoring the development of their child's intelligence, accepting their child about the expectations for achievement by the child, and providing direction to overcome difficulties of a child in completing the tasks of school (Berkowitz, Moore, Astor \& Benbenishty, 2017).

Schuitema, Peetsma, \& Veen (2016) revealed that the attachment between parent and child, the trust of a child to talk about their troubles at school with their parents, and the support of teachers in the classroom, can motivate the child to do things that are challenging and to be enthusiastic in increasing mastery of learning material. This statement is reinforced by several studies that prove that the whole atmosphere at the school and in the classroom determine students' ability to master the materials of subjects (Crede, Wirthwein, McElvany, \& Steinmayr, 2015).

The ability to master learning materials must not only be supported by the external environment of the students, but also be reinforced by internal factors of students, including academic self-efficacy. Self-efficacy is the main construct of Bandura's social cognitive theory. Several studies cited by Ross, Perkins, \& Bodey (2016) have shown that academic self-efficacy has a significant relationship with mastery of English paragraphs writing skills. Academic self-efficacy is associated with, and leads to a desire to master the high language skills. On the other hand, low academic selfefficacy is related to low acquisition of English paragraph writing skills.

Academic self-efficacy contributes to students' beliefs about their ability to master new tasks and skills in an academic context. In the context of school, tasks or skills that must be mastered by students in English lessons include writing skill as one component of language acquisition (Bernacki, Nokes-Malach, \& Aleven, 2015). This academic self-efficacy also shapes the behavior of students toward the learning objectives to be achieved.

Individual behavior is strongly influenced by the culture in which one lives. Koentjaraningrat (2010) suggested that various individual actions, acquired instincts of human genetics, for example, how to eat, drink, or walk, are also shaped by local culture (Steers \& Sánchez-Runde, 2017). This argument suggests that individual behavior is influenced by the individual; in other words, cultural differences will result in a difference in behavior. The content of the Siri' culture contains the values and spirit of competition, hard work, and perseverance to achieve optimal results. These values are considered to contribute to the students' ability to master learning material; and one of the subjects of English, more specifically, the control of the component skills of writing paragraphs, referred to by Pollock \& Waller (2018) as the most difficult component to be mastered by students. Previous studies have not specifically examined the relationship between English language writing skills and student internal factors, namely optimism, perceived social support, academic self-efficacy, and the development of a perception of Siri' cultural values as a mediating factor. However, research in the field of educational psychology is more concerned with learning achievement in English and does not emphasize the components of mastery of language, especially writing skills.

\section{METHODS}

The population of this research comprised 2,556 students. Sampling techniques included simple random sampling with 346 students from three state Islamic senior high schools in South Sulawesi, Indonesia. The background of the locations was selected based on the curriculum content and number of subject (which is greater than that in public state schools). The subjects of 
the research included students (male and female with age range of 16-18 years old). The data employed in this research were obtained through a scale with a self-report format based on reports or statements and the experience and perception of research subjects. The use of self-report refers to Pavot opinion stating that self-report is the right tool with which to express thoughts that are subjective (Pavot, 2007). Data collection tools applied in this research included writing tasks to measure the students' ability to write English paragraphs, as well as scales including an optimism scale, social support scale, academic self-efficacy scale, and scale of the perception of Siri' cultural values.

This research content validity applied expert judgment involving 9 experts and with a signification point .01. Formula to measure content validity coefficient of the research was applying formula which was proposed by Aiken, which later was known by Aiken's $V$. The researchers set a $p$ value $<.01$, which means that the probability of error is $1 \%$, then the value of $V$ is based on the index table $V$ with 5 the category is at least .81 .

Researchers compiled the data collection tools based on experts' opinions and a focused group discussion to obtain indicators of behavior and item statements more in line with actual conditions. Model goodness of fit criteria employed was CMINDF $(\leq 2.00)$, CFI $(\geq .90)$, and RMSEA $(\leq .08)$.

The scaling model item in this research used a modified Likert scale in the form of a statement with a number of answer choices containing levels of conformity to the actual conditions of the respondents who filed claims reveal the students' ability to write paragraphs in response to English questions based on the 2013 curriculum. The evaluation of this writing task was carried out by asking for expert judgments in the group discussion. Meanwhile, to measure students' optimism based on Seligman's theory, student social support was revealed by using a social support scale compiled based on House's concept. The academic self-efficacy variable was measured using a scale developed by Owen and Froman, the College Academic Self-efficacy Scale (CASES). The mediator variable in this research was a scale of the perception of Siri' cultural values based on the Mattulada and Said opinion.

\section{FINDINGS AND DISCUSSION Findings}

The researcher hypothesizes that there is a significant correlation between optimism, social support, and academic self-efficacy in mastery of academic English writing skills mediated by perceptions of Siri' cultural values. Test assumptions on confirmatory factor analysis calculation variables showed that to obtain models fit to some modifications. In this research, the modifications vary, and some have to connect errors between one indicator and another. The measures are taken before performing confirmatory factor analysis of the overall model, as a condition of performing confirmatory factor analysis of the overall model, necessary to test the assumption, which in this case, is the assumption made by critical value in the multivariate analysis. The result shows the number of 36.852 , which means that the distribution of the data is not normal because of greater than \pm 2.58 at a significance level of 1 percent (Ghozali, 2014). In this research, the value of the degree of freedom shows the number 120 , thus the data obtained in this research can be analyzed using structural equation models. The next step is to test the overall model variables. The model proposed in accordance with the hypothesis is presented at Figure 1.

After confirmatory factor analysis, the results show that the model is not qualified as per the proposed model fit, (i.e., the CMINDF value of 2.703 is greater than 2.00 , which is the condition fit model). The RMSEA value also does not support the model fit being above the prescribed standard, at .08 (this model shows a value of .086). Therefore, it can be deducted that the empirical data obtained do not support the proposed theoretical concepts. Thus, it needs modification to obtain a model which is more in line with the data in the field.

Modification of the selected model involved linking errors between behavioral indicators with other behavioral indicators based on advice from the modification indices. The results can be seen in the Figure 2 .

Figure 2 shows the model fits to the criteria CMINDF $(1.885 ;<2.00)$, TLI $(.902 ;>$ $.90)$, and RMSEA $(.066 ;<.08)$, but there was a "Heywood case" between social support and mastery of English paragraphs writing skills which shows the number of $3.06(<1)$. According 


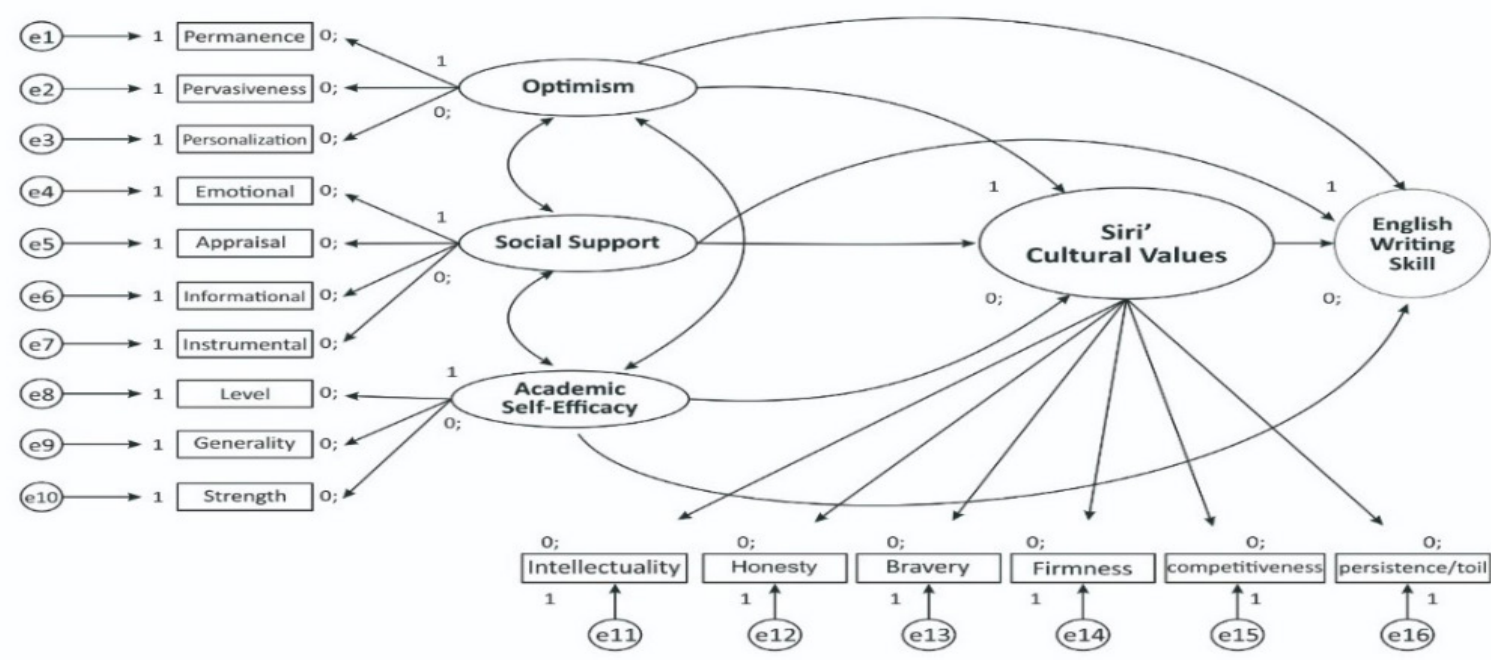

Figure 1. Path Diagram Research

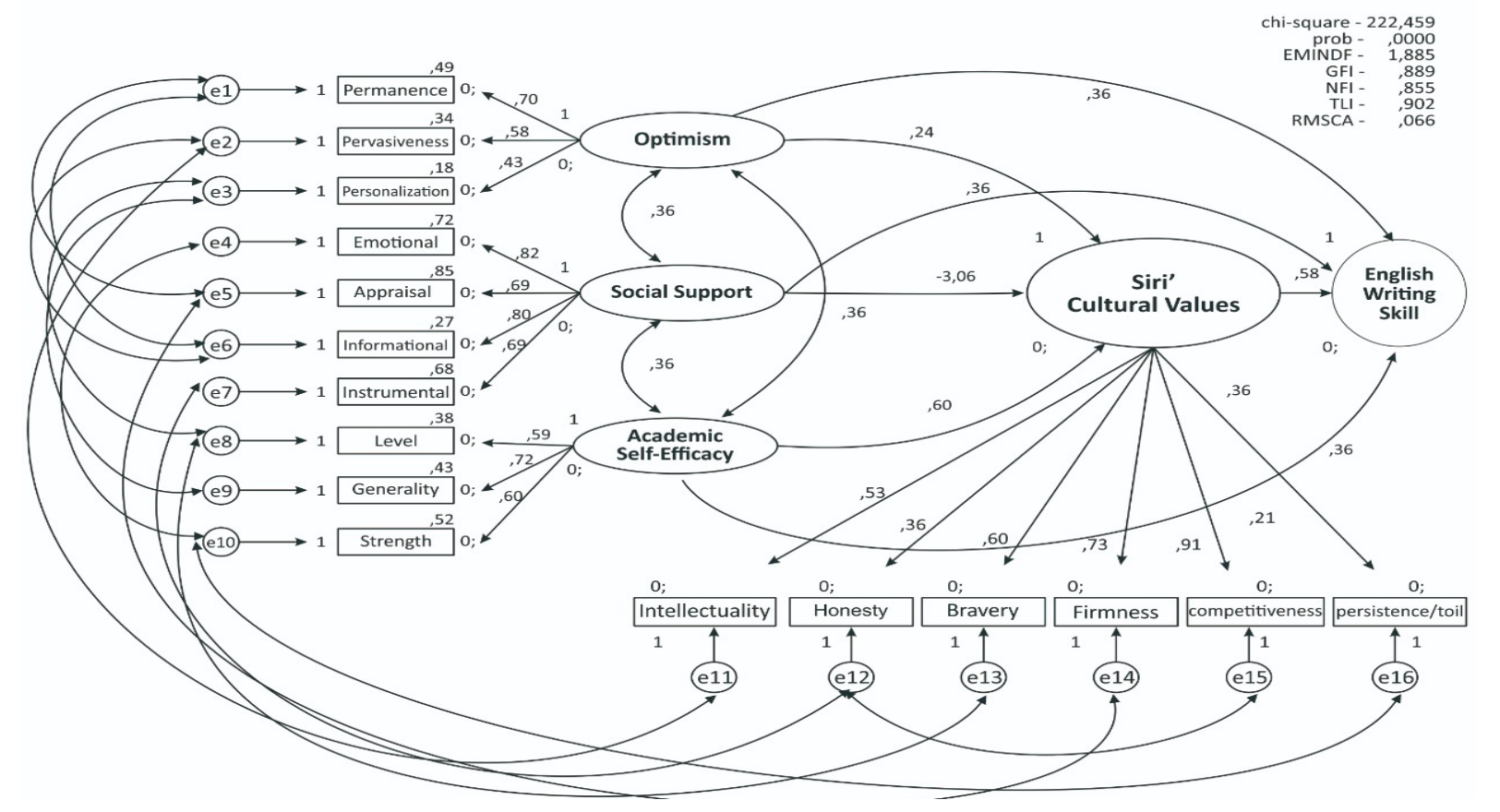

Figure 2. Modification Model of Structural Equation Modelling

to Ghozali (2014), elimination Heywood case can be conducted by adding constraints on the error variance in social support variables. After adding the value of the error variance constraints in social support, the results show that the proposed model meets the criteria, based on the RMSEA value of $.069(<.80)$, CFI value of .916 $(\geq .90)$, and GFI value of $.880(\geq .90)$ which is below the standards set but it is still close to the recommended values, thus the model can be said to be marginally feasible. The model presented at Figure 3.

Based on a model that has been tested it is seen that there are direct and indirect effects between variables. The immediate effect is the relationship between variables that are not mediated by other variables, while the indirect effect relationship between variables is mediated by other variables. The immediate effects of this research comprises optimism with mastery of English paragraph writing skills, social support with mastery of English paragraph writing skills, academic self-efficacy with a mastery of English paragraph writing skills, and perception of Siri' cultural values with mastery of English paragraph writing skills. The results show that optimism significantly influenced mastery of English writing skills in English $(\beta=.580, p=$ 


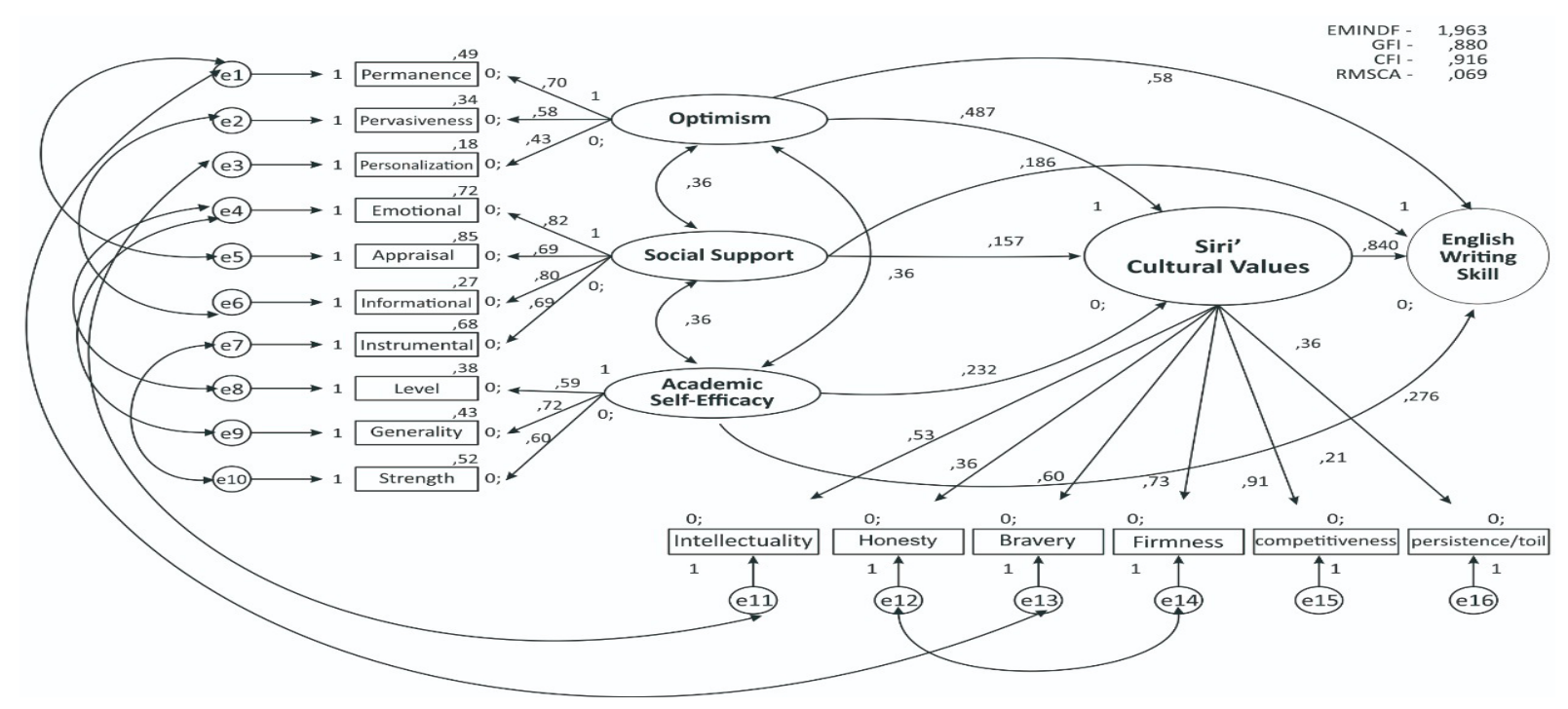

Figure 3. Fit of Structural Equation Model

.004); social support does not affect the mastery of writing skills of English paragraphs $(\beta=$ $.186, p=.274)$; academic self-efficacy does not significantly affect mastery of English paragraph writing skills $(\beta=.276, p=2.000)$; whereas the perception of Siri' cultural values significantly affect mastery of English paragraph writing skills $(\beta=.840, p=.001)$. This result can be seen at Table 1.

Indirect effects mediating the relationship between variables with other variables are also called mediator variables, (i.e., variables that modify the relationship between exogenous and endogenous variables. The results indicate that perception of Siri' cultural values - can act as a mediator variable. The supporting data consist of information regarding that the value of $\beta$ between the value of optimism with mastery of English paragraph writing skills $(\beta=$ .487), which indicate the number is quite large but smaller when compared with the value of $\beta$ between optimism through the perception of Siri' cultural values $(\beta=.840)$.

Value $\beta$ between social support and mastery of English paragraph writing skills $(\beta=$ .157) shows a small value when compared with the value of $ß$ between social support and mastery of English paragraph writing skills through the perception of Siri' cultural values $(\beta=.840)$, thus strengthening the role of the perception of Siri' cultural values as a mediator variable. Similarly, the value of $\beta$ between academic self-efficacy with mastery of English paragraph writing skills $(\beta=.232)$ shows a smaller number than the value of $\beta$ between academic self-efficacy and academic mastery of English paragraph writing skills through the perception of Siri' cultural values $(\beta=.840)$, which as well reinforces the perception of the role of Siri' cultural values as a mediator variable. Statistically, the variables of optimism, social support, and academic selfefficacy play a significant role in the mastery of English paragraph writing skills if they are entered by a variable perception of Siri' cultural values.

From the perspective of this research, variables that become inputs are optimism, social support, academic self-efficacy, perceptions of Siri' cultural values, and variable control of English paragraph writing skills of students as output. To illustrate this more clearly and comprehensively, operation of the model

Table 1. Direct Effect Regression Coefficient Exogenous Against Endogenous Variables

\begin{tabular}{lccc}
\hline \multicolumn{1}{c}{ Exogenous Variables } & Endogenous Variables & Direct Effect & $\boldsymbol{p}$ \\
\hline Optimism & English writing skills & .580 & $<.01$ \\
Social support & English writing skills & .186 & $>.05$ \\
Academic self-efficacy & English writing skills & .276 & $>.05$ \\
Value of Siri'culture & English writing skills & .840 & $<.01$ \\
\hline
\end{tabular}


can be obtained by looking at the value of the loading factor on each of the observed variables. Observed variables in this model describe the aspects contained in the latent variable. In this research, there are four latent variables including optimism, social support, academic self-efficacy, and perceptions of Siri' cultural values. The role of unobserved variables on the latent variables based on the loading factor can be seen in the Table 2 .

The effective contribution of exogenous and endogenous variables in the research can be known through the coefficient of determination. The coefficient of determination is the square of the correlation between variables (squared multiple correlations). In this research, the exogenous variable is divided into two; the first, consisting of variable optimism, social support, and academic self-efficacy, and the second, consisting of the variable perception of Siri' cultural values, the endogenous variable is mastery of English paragraph writing skills. The coefficient of determination exogenous variables shows a figure of .986, in other words the effective contribution of the variables of optimism, social support, and academic self-efficacy, to the mastery of English paragraph writing skills amount to $98.6 \%$. Then, in the second stage, the exogenous variable is the perception of Siri' cultural values with the endogenous variable, students' mastery of English paragraph writing skills. The resulting coefficient of determination is .706 , in other words, the variable perception of Siri' cultural values provides the effective contribution of $70.6 \%$ on the acquisition of students' skills of English paragraphs writing skills. Tabel 3 shows this result.

Different test measures intend variables to enrich discussion. This research will be the difference in terms of gender variable. Role gender of the research variables can be known through the mean difference between the subject of men and women, by means of analytical techniques $F$ test result is shown in the Table 4 .

Table 2. Observed Variables Role Against Latent Variables

\begin{tabular}{clcc}
\hline \multicolumn{1}{c}{ Latent Variables } & \multicolumn{1}{c}{ Observed Variables } & Loading Factor & $\boldsymbol{p}$ \\
\hline \multirow{3}{*}{ Optimism } & Permanency & .447 & $<.01$ \\
& Pervasive & .566 & $<.01$ \\
& Personalization & .716 & $<.01$ \\
& Emotional & .850 & $<.01$ \\
& Appraisal & .644 & $<.01$ \\
& Information & .587 & $<.01$ \\
& Instrumental & .627 & $<.01$ \\
& Level & .671 & $<.01$ \\
Academic self-efficacy & Generality & .749 & $<.01$ \\
& Strength & .483 & $<.01$ \\
& Intellectuality & .592 & $<.01$ \\
& Honesty & .820 & $<.01$ \\
& Bravery & .724 & $<.01$ \\
Value of Siri' culture & Firmness & .716 & $<.01$ \\
& Competitiveness & .447 & $<.01$ \\
& Persistence/toil & .587 & $<.01$ \\
\hline
\end{tabular}

Table 3. Coefficient of Determination

\begin{tabular}{llcc}
\hline \multicolumn{1}{c}{ Exogenous Variables } & \multicolumn{1}{c}{ Endogenous Variables } & $\begin{array}{c}\text { Coefficient } \\
\text { Determination }\left(\boldsymbol{R}^{2}\right)\end{array}$ & $\begin{array}{c}\text { Effectiveness } \\
(\mathbf{\%})\end{array}$ \\
\hline $\begin{array}{l}\text { Optimism, social support, } \\
\text { academic self-efficacy }\end{array}$ & $\begin{array}{l}\text { Writing skills English } \\
\text { paragraph }\end{array}$ & .986 & 98.6 \\
Value of Siri'culture & $\begin{array}{l}\text { Writing skills English } \\
\text { paragraph }\end{array}$ & .706 & 70.6 \\
\hline
\end{tabular}


Table 4. T-test Result

\begin{tabular}{lcccccc}
\hline \multirow{2}{*}{ Variables } & \multirow{2}{*}{$\boldsymbol{F}$ Value } & \multirow{2}{*}{} & \multicolumn{3}{c}{$\boldsymbol{N}$} & \multicolumn{2}{c}{ Mean } \\
\cline { 4 - 7 } & & & Male & Female & Male & Female \\
\hline English writing skills & 6.523 & $<.05$ & 142 & 204 & 33.51 & 35.00 \\
Optimism & 5.409 & $<.05$ & 142 & 204 & 39.29 & 40.99 \\
Social support & 5.412 & $<.05$ & 142 & 204 & 27.40 & 28.69 \\
Academic self-efficacy & 7.008 & $<.05$ & 142 & 204 & 52.61 & 55.30 \\
Value of Siri' culture & 6.068 & $<.05$ & 142 & 204 & 39.66 & 41.63 \\
\hline
\end{tabular}

The Table 4 shows that there is a difference between men and women for the variables: control of writing skills, optimism, social support, academic self-efficacy, and Siri' cultural values. These results indicate gender effect on the control variables: English writing skills, optimism, social support, academic selfefficacy, and perceptions of Siri'cultural values.

The mean difference between males and females in terms of mastery of English paragraph writing skills can only be due to differences in learning self-regulation among males and females. Female students are more diligent and industrious, have a plan and a better goal, in the context of writing. Female students are slightly better in terms of fine motor skills, and female students are more motivated to learn than male students. The results are consistent with research conducted by Achtziger, Hubert, Kenning, Raab, \& Reisch (2015), who found that there were significant differences in males and females in terms of set goals and organized efforts to achieve learning goals. Monitoring themselves with metacognitive abilities, by organizing time, and regulating their social environment, female students are better at mastering English paragraph writing skills.

Results of different test variables based on gender studies also indicate differences in social support between males and females. This may be due to people perceive that men and women differ not only in terms of the physical, but also in terms of how they think (Pennycook, Cheyne, Koehler, \& Fugelsang, 2016). There is a stereotype that women's thinking involves perceived feelings, while men think using advanced logic. This is what makes women more expressive of their need for social support than men; therefore, female students better at perceiving social support than male students.

\section{Discusion}

In education in Indonesia, many ways have been tried and implemented to improve student learning achievement, through curriculum changes, teacher training regarding creating of a good learning climate, and many more, however the phenomenon of low student academic achievement, especially in English, remains visible. The efforts of the education sector in Indonesia as mentioned before have involved changing or improving the external factors of students, however as far as the researcher' understanding it has not specifically highlighted internal factors, in this case, optimism, social support, academic self-efficacy, and students' perception of the value of their own culture.

The context of mastering English paragraph writing skills is influenced by various factors, both internally and externally. Internally, the ability to write a paragraph of English skill is influenced by optimism, interest, motivation, experience, and habits (Sumekto \& Setyawati, 2018).

\section{Dispositional Optimism}

The results of this research are consistent with the research of Dixson, Worrell, OlszewskiKubilius, \& Subotnik (2016), who state that optimism can lead to the belief that every problem can be solved by looking on the bright side. By relying on students' beliefs, all challenges, including completing writing tasks in English subjects, can be completed. Individuals who think positively will not be easily discouraged by obstacles encountered. Optimism can be a kind of psychological immunization to counteract various problems faced by students in school, especially related to the completion of given tasks. Optimism is related to how individuals judge events objectively and rationally. Therefore, optimism is deeper than just positive thinking. Fundamentally, optimism is not only a 
statement or expression to encourage oneself; it can also be thought of as the cause of an incident.

Research conducted by Little, Clark, Tani, \& Connor (2018) found that individuals in many ways built unrealistic and conceptualized optimism as an attitude. The possibility of uncertainty about expectations about the future as opposed to the past, which will lead individuals to overestimate or underestimate. In line with the research of Little et al. (2018); Rakedzon \& Baram-Tsabari (2017) stated that optimism is a positive psychological attribute, but it becomes negative if the optimism is excessive. Excessive optimism has a negative impact on oneself and others. Individuals who have excessive optimism always ignore negative information or facts that are relevant to the situation to be faced. Due to such neglect, the individual concerned cannot see the reality that will happen to him. He did not have the preparation needed to deal with that reality. Based on this description, optimism is a psychological force that causes individuals to have the hope that they will gain success through the hard work they do. Optimism also involves expectations and ways of describing the future of individuals and the consequences of those perspectives (negative or positive) on success or failure in the form of behavior in the present.

\section{Perceived of Social Support}

In addition, the results of this research show that social support did not affect the mastery of English paragraph writing skills. The results of this research are parallel with the research conducted by Wijekumar, Graham, Harris, Lei, Barkel, Aitken, \& Houston (2018), considering social support as a process of resource transactions between individuals who can provide assistance, enthusiasm, acceptance, and attention. The understanding between individuals in the process (social support) allows them to work together and exchange necessary resources that are not only material but can also be in the form of advice.

This is, of course, different from the research results of Weisz, Quinn, \& Williams (2015), stating that social support improves productivity through increased motivation, quality of reasoning, psychological well being, self-adjustment capability, and improved selfesteem. Analogous to previous research, Chen, Huang, Chang, \& Liou (2015) suggested that social support controls the existence of social bonds outside of individuals, which are used to improve the ability to deal with conflict, like students who face difficulties in doing English writing assignments.

Social support is assumed to be immensely useful to improve the mastery of English subjects, in this case, the writing skill of English students, yet reality shows that the social support needed depends on the individual. Individuals who have a high need of affiliation also require greater social support compared with individuals with a low need for affiliation. It may also be influenced by students' interest in certain subjects. In other words, students who are interested in certain subjects are more intrinsically motivated than extrinsically influenced.

\section{The Effect of Self-efficacy on Academic Success}

The results of this research also revealed that academic self-efficacy did not significantly affect the mastery of English paragraph writing skills. The results of this research are similar to that of the research conducted by Ennis \& Jolivette (2014), showing that individuals with low academic self-efficacy easily gave up and despaired when faced with difficulties and problems. Low academic self-efficacy is seen when situations arise that suppress emotional conditions. Emotional turmoil, deep anxiety, and weak physiological conditions experienced by an individual will be felt as a signal that an unwanted event will occur. Anxiety and stress that occur in an individual when performing tasks are often interpreted as a failure. In general, students tend to expect success in conditions that are not characterized by tension in completing their tasks at school.

The results of this research differ from those found by Cassidy (2015), which mentioned that academic self-efficacy is the basis for a student's motivation, well-being, or affective and personal accomplishment condition. Academic self-efficacy can help students to determine the action to be taken based on knowledge and skills. Bandura (2014) said that what is known by the individual (knowledge), the skills possessed, or the achievement of something previously produced are often poor predictors of the achievement of subsequent performance (Lee, Lee, \& Bong, 2014). 
The way individuals behave can more often be better predicted based on beliefs about their capabilities than their actual capabilities. In other words, students who have had experience of failure or have had negative perceptual experiences within the context of successful academic performance become weak in academic self-efficacy. Moreover, an English course is still considered "a chore" for some students. However, this does not mean that an individual can complete a task when capability is limited; harmonization is required between self-confidence, on the one hand, and the skills and knowledge needed, on the other.

\section{Siri' as Local Wisdom of Bugis-Makassar}

The results also reveal that the perception of Siri' cultural values has a significant effect on the mastery of English paragraph writing skills. This result is consistent with the assumptions built in the early literature that Siri' has a psychological bearing capacity for encouraging enthusiasm to work hard in order to achieve the desired goal. In the context of this research, the Siri' referred to is that which can foster a sense of shame and lead to efforts to maintain, improve, and make every effort so that students are able to master the learning materials and succeed academically.

Based on the researches conducted by the researcher, there is no research linking achievement and local cultural values. What is available is a culture-based education model, an educational model that becomes a collaborative effort involving participation and the role of the wisdom of the cultural value system in it. Participation in this context is in the form of cooperation between citizens and the government in planning, implementing, maintaining and developing educational activities based on the root of the system's own cultural values, which is completely different from what the researcher did. (Zuchdi \& Nurhadi, 2019)

Perception of Siri' cultural values was more directed at seeing how students' implementation of the Siri' culture contributed to a passion for achievement, especially in English subjects described previously, mastery of English is a necessity to be able to compete in the era of globalization, which emphasizes the quality of human resources as a determining factor for the independence of a nation.

\section{Enhancing Writing Skills}

The results also reveal a determination of the coefficient calculation of exogenous variables on the endogenous variable that is equal to .986; in other words, the effective contribution of the variables of optimism, social support, and academic self-efficacy; to mastery of English paragraphs writing skills amounted to 98.6 percent. The results support the research conducted by Carver and Oladayo that found optimism is the belief of individuals that events or unpleasant experiences are only temporary and do not affect all activities; they are caused not only by themselves but also by circumstances, fate, or others reasons (Carver \& Scheier, 2014). Students who are optimistic use problem-focused coping and less denial when faced with problems completing tasks in school.

In contrast, research conducted by $\mathrm{Ju}$, Shin, Kim, Hyun, \& Park (2013), which states that optimists make life disproportionate because thoughts and decisions bring out differences. The development of a healthy pessimist means the individual always analyzes and prepares the situation to fix anything that seems inappropriate. Healthy pessimism also allows individuals to have empathy and sympathy.

Similarly, with respect to social support perceived by students, social support is regarded as a transaction process between individual sources from one individual to another. The transaction process is expected to provide support, encouragement, acceptance, and attention. Research conducted by Maier, Laumer, Eckhardt, \& Weitzel (2015) states that in social support there is a mutual understanding among individuals that they can mutually cooperate and exchange necessary resources, including tangible material and information and also intangible advice or referrals. That is to say, students having interaction in school can provide mutual understanding and cooperation to support mastery of the subject matter that has not been controlled, including in the subjects of English.

Unlike the previous opinion that social support is assumed to be beneficial for individuals physically and psychologically. Research by Siedlecki, Salthouse, Oishi, \& Jeswani (2014) states that not all the support given to other individuals is felt to be beneficial by those concerned because the function of social support is influenced by individual perceptions of their 
environment, or, the extent to which individuals feel their need for support is fulfilled.

Academic self-efficacy has become one of the variables considered to contribute adequately to increasing mastery of learning material, especially in the subjects of English. The results of this research show no correlation between academic self-efficacy with mastery of English paragraph writing skills, even though the correlation is not significant. The results are consistent with research conducted by Zee \& Koomen (2016), stating that individuals who have fear and anxiety will fail in completing a task, which will have an impact on the individual's belief in doing his or her job. Students who are not confident in completing a task will tend to fail. High and low academic self-efficacy, when associated with an environment that is responsive and unresponsive will produce four kinds of relationships, namely: (1) if the high self-efficacy and environmentally responsive individuals will be successful; (2) if the low selfefficacy and responsive environment then people will get depressed when seeing other people succeed in a task that is considered difficult; (3) if the high self-efficacy and less responsive environment individuals will be prostest through social movements or the power to force change, but if the business fails they will give up and find another way to look for a new environment that is more responsive; (4) if the low self-efficacy and less responsive environment individuals will be apathetic and surrender helplessly (Chong, Liem, Huan, Kit, \& Ang, 2018).

Human subjective experience is an assumption of positive and negative thinking that fuses to form self-efficacy. Bandura (2014) assumes that feelings of weakness in the physical and psychological can control self-efficacy. Self-efficacy is formed by personal judgment and adoption of social environment prejudices (Galla, Wood, Tsukayama, Har, Chiu, \& Langer, 2014).

The results are consistent with research conducted by Horlings, stating that students with perceptions of high espoused cultural values will always strive to perform and to appear as the winner, with strong ambition characterized by the spirit of learning to master every learning difficulty faced (Horlings, 2015); mastering writing skills as one component of mastery of the English language, is to be conducted as part of an effort to reach success in the learning process. Such students have the spirit to compete to become the best in their class. This spirit is embodied in the form of mobilization capability and all efforts to produce a winner, or at least among the ranks of students who have the best performance. However, faults in perceiving cultural values result in the emergence of shame to recognize local culture and look down one's own cultural values (Rivas-Drake, Seaton, Markstrom, Quintana, Syed, Lee, \& Yip, 2014).

The research also found an indirect effect of the proposed model. The results show that the perception of cultural values Siri' can act as a mediator variable. Results of regression calculation show that the value of $\beta$ between the value of optimism with mastery of English paragraph writing skills indicates the number is quite large, but it is small compared to the value of $\beta$ between optimism, social support, and academic self-efficacy, through the perception of Siri' cultural values. This means that students who are able to perceive the series of cultural value will find it easier to achieve success in the academic field, especially in the mastery of subject matter including English.

Learning systems that promote Siri' cultural values require that educators be imaginative and creative to pursue a strategy of relevant teaching and be able to build motivation consistently and persistently for students to be able to compete in mastering learning material, especially in the subjects of English language. Students who have a high perception of Siri' cultural values will demonstrate perseverance, be meticulous and careful, have discipline, be delighted by challenges and responsibilities, and dare to take risks.

\section{CONCLUSION}

First, the theoretical model proposed concerning the perception of Siri' cultural values as a variable that mediates the relationship between optimism, social support, and academic self-efficacy is accepted. The variables that used as the driving machine are Siri' cultural values, and the input variables are optimism, social support, and academic self-efficacy. Data in the field can test the model so that the relationship between optimism, social support, and academic self-efficacy with the mastery of English writing skills will be strengthened if students are able to 
perceive the value of Siri' culture well. Second, the findings of this research show that the most dominant factor in achieving students' mastery of English writing skills is optimism. Optimism influences students to be able to think and act positively when facing difficulties that might exist in the learning process, especially in mastering English writing skills.

The frequency distribution categorization in this research also shows that the majority of students who become research subjects have a level of optimism, social support, perception of siri 'cultural values, and mastery of English paragraph writing skills at a moderate level, only the level of academic self-efficacy of research subjects is at rather high category. Moreover, this research does not imply interdependence among variables. However, the role of perceptions of Siri' cultural values remains prominent to support optimism, social support, academic self-efficacy, and mastery of students' English paragraph writing skills. Consequently, there is an opportunity to provide a kind of training for students in order to revitalize Siri' cultural values for students. In addition to training to interpret Siri' cultural values, other training that can be done includes training in positive thinking thus students' optimism, social support and academic self-efficacy may improve.

As previously noted, it is recommended for future research to test the models by using different research subjects, environments, and cultures and also pay attention to the negative impact of the development of information technology for students' psychological development. This should be done to obtain a more accurate description of the relationship between students' psychological factors and their ability to master foreign languages, especially English.

\section{ACKNOWLEDGEMENT}

This research was supported by Achmad Nurmandi and Khoiruddin Bashori from Universitas Muhammadiyah Yogyakarta. The researcher would like to express his immense gratitude to both his supporters who have provided insight and expertise that greatly assisted the research.

\section{REFERENCES}

Achtziger, A., Hubert, M., Kenning, P., Raab,
G., \& Reisch, L. (2015). Debt out of control: The links between self-control, compulsive buying, and real debts. Journal of Economic Psychology, 49(August), 141-149. doi:10.1016/j.joep.2015.04.003.

Alqahtani, M. (2015). The importance of vocabulary in language learning and how to be taught. International Journal of Teaching and Education, 3(3), 21-34. doi:10.1016/0883-0355(87)90001-2.

Bandura, A. (2014). Exercise of personal agency through the self-efficacy mechanism. New York, NY: Routledge.

Berkowitz, R., Moore, H., Astor, R. A., \& Benbenishty,R.(2017). aresearchsynthesis of the associations between socioeconomic background, inequality, school climate, and academic achievement. Review of Educational Research, 87(2), 425-469. doi:10.3102/0034654316669821.

Bernacki, M. L., Nokes-Malach, T. J., \& Aleven, V. (2015). Examining self-efficacy during learning: variability and relations to behavior, performance, and learning. Metacognition and Learning, 10(1), 99117. doi:10.1007/s11409-014-9127-x.

Bruning, R., Dempsey, M., Kauffman, D. F., McKim, C., \& Zumbrunn, S. (2013). Examining dimensions of self-efficacy for writing. Journal of Educational Psychology, 105(1), 25-38. doi:10.1037/ a0029692.

Carver, C. S., \& Scheier, M. F. (2014). Dispositional optimism. Trends in Cognitive Sciences, 18(6), 293-299. doi:10.1016/j.tics.2014.02.003.

Cassidy, S. (2015). Resilience building in students: The role of academic selfefficacy. Frontiers in Psychology, 6, 1781, 1-14. doi:10.3389/fpsyg.2015.01781.

Chen, M.-H., Huang, S.-T., Chang, J. S., \& Liou, H.-C. (2015). Developing a corpusbased paraphrase tool to improve EFL learners' writing skills. Computer Assisted Language Learning, 28(1), 22-40. doi:10. 1080/09588221.2013.783873. 
Chong, W. H., Liem, G. A., Huan, V. S., Kit, P. L., \& Ang, R. P. (2018). Student perceptions of self-efficacy and teacher support for learning in fostering youth competencies: Roles of affective and cognitive engagement. Journal of Adolescence, 68, 1-11. doi:10.1016/j. adolescence.2018.07.002.

Crede, J., Wirthwein, L., McElvany, N., \& Steinmayr, R. (2015). Adolescents' academic achievement and life satisfaction: the role of parents' education. Frontiers in Psychology, 6(52), 1-8. doi:10.3389/fpsyg.2015.00052.

Dixson, D. D., Worrell, F. C., OlszewskiKubilius, P., \& Subotnik, R. F. (2016). Beyond perceived ability: The contribution of psychosocial factors to academic performance. Annals of the New York Academy of Sciences, 1377(1), 6777. doi:10.1111/nyas.13210.

Ennis, R. P., \& Jolivette, K. (2014). Using self-regulated strategy development for persuasive writing to increase the writing and self-efficacy skills of students with emotional and behavioral disorders in health class. Behavioral Disorders, 40(1), 26-36. doi:10.17988/0198-7429-40.1.26.

Galla, B. M., Wood, J. J., Tsukayama, E., Har, K., Chiu, A. W., \& Langer, D. A. (2014). A longitudinal multilevel model analysis of the within-person and between-person effectofeffortful engagementandacademic self-efficacy on academic performance. Journal of School Psychology, 52(3), 295308. doi:10.1016/j.jsp.2014.04.001.

Ghozali, I. (2014). Model persamaan struktural: Konsep dan aplikasi dengan program AMOS 24. [Structural equation model: Concepts and applications with the AMOS 24 program]. Semarang: Badan Penerbit Universitas Diponegoro.

Horlings, L. G. (2015). The inner dimension of sustainability: Personal and cultural values. Current Opinion in Environmental Sustainability, 14(June), 163-169. doi:10.1016/j.cosust.2015.06.006.
Jaeger, M. M. (2011). Does cultural capital really affect academic achievement? New evidence from combined sibling and panel data. Sociology of Education, 84(4), 281298. doi:10.1177/0038040711417010.

Jalaluddin, I., Paramasivam, S., Husain, S., \& Bakar, R. A. (2015). The consistency between writing self-efficacy and writing performance. Journal of Language Teaching and Research, 6(3), 545-552. doi:10.17507/jitr.0603.09.

Ju, H., Shin, J. W., Kim, C.-w., Hyun, M.-h., \& Park, J.-w. (2013). Mediational effect of meaning in life on the relationship between optimism and well-being in community elderly. Archives of Gerontology and Geriatrics, 56(2), 309-313. doi:10.1016/j. archger.2012.08.008.

Koentjaraningrat, K. (2010). Manusia dan kebudayaan di Indonesia. [Humans and culture in Indonesia]. Jakarta: Djambatan.

Lee, W., Lee, M.-J., \& Bong, M. (2014). Testing interest and self-efficacy as predictors of academic self-regulation and achievement. Contemporary Educational Psychology, 39(2), 86-99. doi:10.1016/j. cedpsych.2014.02.002.

Little, C. W., Clark, J. C., Tani, N. E., \& Connor, C. M. (2018). Context and implications document for: improving writing skills through technology-based instruction: A meta analysis. Review of Education, 6(2), 202-204. doi:10.1002/rev3.3115.

Mackinnon, S. P. (2012). Perceived social support and academic achievement: Cross-lagged panel and bivariate growth curve analyses. Journal of Youth Adolescence, 41(4), 474485. doi:10.1007/s10964-011-9691-1.

Maier, C., Laumer, S., Eckhardt, A., \& Weitzel, T. (2015). Giving too much social support: Social overload on social networking sites. European Journal of Information Systems, 24(5), 447-464. doi:10.1057/ ejis.2014.3.

Morton, S., Mergler, A., \& Boman, P. (2014). Managing the transition: The role of 
optimism and self-efficacy for first-year australian university students. Journal of Psychologists and Counsellors in Schools, 24(1), 90-108. doi:10.1037/a0029692.

Niño, F. L., \& Páez, M. E. (2018). Building writing skills in english in fifth graders: Analysis of strategies based on literature and creativity. Canadian Center of Science and Education, 11(9), 102-117. doi:10.5539/elt.v11n9p102.

Pavot, W. (2007). The assesment of subjective well-being. In M. Eid, \& R. J. Larsen (Eds.). The science of subjective wellbeing. New York, NY: The Guilford Press, pp. 120-146.

Pennycook, G., Cheyne, J. A., Koehler, D. J., \& Fugelsang, J. A. (2016). Is the cognitive reflection test a measure of both reflection and intuition? Behavior Research Methods, 48(1), 341-348. doi:10.3758/ s13428-015-0576-1.

Pollock, J., \& Waller, E. (2018). Paragraph. In J. Pollock, \& E. Waller (Eds.). English grammar and teaching strategies: Lifeline to literacy. London: David Fulton Publishers, pp. 1-32.

Rahman, R. (2007). Pemberdayaan gambar dan kartu kata dalam pembelajaran menulis. [Empowerment of images and word cards in learning to write]. In Sunandar, D. (Ed). Pemikiran-pemikiran inovatif dalam kajian bahasa, sastra, seni, dan pembelajaran: Forum ilmiah $I$ \& II UPI. Bandung: Universitas Pendidikan Indonesia.

Rakedzon, T., \& Baram-Tsabari, A. (2017). To make a long story short: A rubric for assessing graduate students' academic and popular science writing skills. Assessing Writing, 32(April), 28-42. doi:10.1016/j. asw.2016.12.004.

Rivas-Drake, D., Seaton, E. K., Markstrom, C., Quintana, S., Syed, M., Lee, R. M., \& Yip, T. (2014). Ethnic and racial identity in adolescence: Implications for psychosocial, academic, and health outcomes. Child Development, 85(1), 40-
57. doi:10.1111/cdev.12200.

Ross, M., Perkins, H., \& Bodey, K. (2016). Academic motivation and information literacy self-efficacy: The importance of a simple desire to know. Library \& Information Science Research, 38(1), 2-9. doi:10.1016/j.lisr.2016.01.002.

Schuitema, J., Peetsma, T., \& Veen, I. v. (2016). Longitudinal relations between perceived autonomy and social support from teachers and students' self-regulated learning and achievement. Learning and Individual Differences, 49(July), 32-45. doi:10.1016/j.lindif.2016.05.006.

Schultz, C.(2009). Mathematical communication and achievement through journal writing. (Master Thesis, University of NebraskaLincoln). https://digitalcommons.unl.edu/ mathmidsummative/27.

Siedlecki, K. L., Salthouse, T. A., Oishi, S., \& Jeswani, S. (2014). The relationship between social support and subjective well-being across age. Social Indicators Research, 117(2), 561-576. doi:10.1007/ s11205-013-0361-4.

Sivandani, A., Koohbanani, S. E., \& Vahidi, T. (2013). The relation between social support and self-efficacy with academic achievement and school satisfaction among female junior high school students in birjand. Social and Behavioral Sciences, 84(July), 668-673. doi:10.1016/j. sbspro.2013.06.623.

Song, J., Bong, M., Lee, K., \& Kim, S-i. (2015). Longitudinal investigation into the role of perceived social support in adolescents' academic motivation and achievement. Journal of Educational Psychology, 107(3), 821-841. doi:10.1037/ edu0000016.

Steers, R. M., \& Sánchez-Runde, C. J. (2017). Culture, motivation, and work behavior. In M. J. Gannon, \& K. L. Newman (Eds.). Handbook of cross-cultural management. New Jersey, NJ: Blackwell Publishers Ltd, pp. 190-216. 
Sumekto, D. R., \& Setyawati, H. (2018). Students' descriptive writing performance: The analytic scoring assessment usage. Cakrawala Pendidikan, 37(3), 413-425. doi:10.21831/cp.v38i3.20033.

Tsang, S. K. M., Hui, E. K. P., \& Law, B. C. M. (2011). Self-efficacy as a positive youth development construct: A conceptual review. The Scientific World Journal, 2012(102), 4381-4387. doi:10.1100/2012/452327.

Warikoo, N., \& Carter, P. (2009). Cultural explanations for racial and ethnic stratification in academic achievement: A call for a new and improved theory. Review and Educational Research, 79(1), 366394. doi:10.3102/0034654308326162.

Weisz, B. M., Quinn, D. M., \& Williams, M. K. (2015). Out and healthy: Being more "out" about a concealable stigmatized identity may boost the health benefits of social support. Journal of Health Psychology, 21(12), 2934-2943. doi:10.1177/1359105315589392.

Wibrowski, C. R., Matthews, W. K., \& Kitsantas, A. (2017). The role of a skills learning support program on first-generation college students' selfregulation, motivation, and academic achievement: A longitudinal study. Journal of College Student Retention: Research, Theory \& Practice, 19(3), 317332. doi:10.1177/1521025116629152.

Wijekumar, K., Graham, S., Harris, K. R., Lei, P.-W., Barkel, A., Aitken, A., \& Houston, J. (2018). The roles of writing knowledge, motivation, strategic behaviors, and skills in predicting elementary students' persuasive writing from source material. Reading and Writing, 32(6), 1431-1457. doi:10.1007/s11145-018-9836-7.

Zee, M., \& Koomen, H. M. (2016). Teacher self-efficacy and its effects on classroom processes, student academic adjustment, and teacher well-being: A synthesis of 40 years of research. Review of Educational Research, 86(4), 981-1015. doi:10.3102/0034654315626801.

Zuchdi, D., \& Nurhadi, N. (2019). Culture based teaching and learning for indonesian as foreign language in yogyakarta. Cakrawala Pendidikan, 38(3), 465-476. doi:10.21831/cp.v38i3.26297. 